\title{
Investigating the Relationship between Intellectual Capital and Audit Quality Based on China Audit Market
}

\author{
Meng Chao ${ }^{1^{*}}$, Dewi Fariha Abdullah ${ }^{2}$, Norhalimah Idris ${ }^{3}$ \\ ${ }^{1,2,3}$ Azman Hashim International Business School, Universiti Teknologi Malaysia, Johor Bahru, Malaysia
}

*Corresponding Author: Meng Chao, Azman Hashim International Business School, Universiti Teknologi Malaysia, Johor Bahru, 81310, Johor, Malaysia, mengchaoacca@163.com

\begin{abstract}
Audit quality is often considered as the probability that auditors can detect and report misstatements of clients' financial reporting, and enhance the credibility of stakeholders on disclosed information. Hence, the importance of intellectual capital can be tracked to the audit quality of accounting firms with knowledge-intensive feature. This paper discusses a more comprehensive perspective of intellectual capital in auditing area, with the opinion that all of the four components will have critical impact on audit quality. Not only human capital and spiritual capital including such as knowledge, skills, expertise, ethics, moral and values etc., but also the rules, systems, norms within the firm and the relationship characteristics of the firm with its clients are all closely related to audit quality. This paper introduces a more complete conceptual framework of intellectual capital on the basis of exploring the factors mentioned in previous studies and discusses the influencing factors of intellectual capital on audit quality, and finally puts forward some suggestions on the structure of intellectual capital, the internal management of accounting firms and industry supervision based on China's audit market.
\end{abstract}

Keywords: Intellectual Capital; Human Capital; Audit Quality; Audit Independence

\section{INTRODUCTION}

Accounting firms are special service organizations characterized with less physical assets but more intangible assets, that is intelligence-intensive, and rely largely on the skills and knowledge of audit professionals. They are knowledge-intensive service agencies that provide professional knowledge-based intermediate services to users (Hui \& Chen, 2019; Kaawaase, Bananuka, Kwizina, \& Nabaweesi, 2019). Then intellectual capital (IC) especially human capital plays a key role as an important strategic resource in auditing, and the level of IC may directly affect the competitiveness and viability of the firm (Wu Zhanxia, 2011). However, in order for talents to exert their professional ability, it is necessary to establish supporting systems, including rules, policies and procedures etc., and maintain a good relationship with the external world, both of which provide the necessary platform for the realization of human capital value. Then structural capital and relational capital are also necessary to be emphasized for accounting firms (Lee \& Lin, 2019). In addition to professional competence contributing to audit quality, auditors need to have a high level of faith, values and morality to maintain independent attitude, especially when 
they face pressure from the clients and get stuck in ethical dilemmas (Mappanyuki, 2016; Naslmosavi \& Jahanzeb, 2017). While auditing as a kind of special service product, the quality is the lifeline of the accounting firm. Therefore, the central issue of this study is to explore the relationship between IC and audit quality of accounting firms.

\section{LITERATURE REVIEW AND HYPOTHESIS DEVELOPMENT}

\section{OVERVIEW OF INTELLECTUAL CAPITAL}

Intellectual capital (IC) has been extensively studied in literatures to demonstrate its important contribution to the business success and sustainable development of the organization. According to the widely accepted classification of "H-S-R" (B Marr, 2008; Bernard Marr \& Moustaghfir, 2005), IC is often interpreted as three components, human capital, structural capital and relational capital. Among them, human capital refers to the knowledge-based workforce with competence, knowledge, skills, expertise, qualifications or education; structural capital is the organizational intangibles involving innovation and process capital, and the former includes patents, trademarks, copyrights, while the latter mainly refers to operation procedures, systems, rules, strategies etc.; relational capital basically implies the relationships with external parties, such as customers, authorities and suppliers etc., that is often reflected in communication, cooperation, customer loyalty, brand image and reputation (Cagáňová, Hlásniková, Vraňaková, \& Chlpeková, 2019; F. Nancy, 2020; Hui \& Chen, 2019; Lee \& Lin, 2019). And one empirical study concludes that it is these three components that have major effect on the performance of CPA industry from the perspective of IC theory (Lee \& Lin, 2019).

Additionally, another component is put forward into the IC model, which has been validated by a study on the relationship of IC and corporate performance (Abdullah, 2014), that is spiritual capital. Generally, spiritual capital represents an important value internalized in individuals or the culture of an organization, such as morality, faith, belief, honesty, commitment, motivation and so on (Ismail, 2005; Long \& Mills, 2010; Malloch, 2010). That's exactly right that these values can better constrain and manage personal behavior and judgment, and urge them to perform tasks according to standards and laws, thereby improving the quality of their work. Indeed, the recognition of the spiritual sources of employees will help to achieve the objectives of organization as a whole (Porth, McCall, \& Bausch, 1999).

Therefore, it can be seen that spiritual capital does affect the performance of the organization (Roosevelt Malloch \& Naughton, 2010), and also it enhances the functions of the other three components, which is actually the "Intellectual Capital Central-Triangle Model" proposed by the study of Ismail (2005). In his study, a large group of cases were tested to validate the inclusion of spiritual capital and its central positon in IC model, since it has mutual influence with the other existing components. Finally, the IC model with four-dimensions seems to be comprehensive, inclusive, relevant and practical (Abdullah, 2014).

\section{Human Capital AND AUdit QUality}

Most of the literatures on IC take human capital as the prominent component compared with others, since any achievement of an organization even the advancement of the society can be considered to be created by human power, intelligence and distinguished knowledge (Abdullah, 2014). Human capital is the most important resource for organizations to improve the efficiency and efficacy, and hence gain advantages in service quality of organizations (El-Bannany, 2008). Referring to the previous literature, it can be seen that human capital is the collective knowledge, skills and expertise of the individuals in the organization (Bontis, Keow, \& Richardson, 2000). The knowledge can be used to create more wealth, increase the efficiency of physical assets, increase the value of other types of capital, and enable organizations to deliver high-quality services (Wu Zhanxia, 2011). 
References on audit state that auditors with competent knowledge and skills can provide highquality service (Cheng, Liu, \& Chien, 2009; Naslmosavi \& Jahanzeb, 2017; Roosevelt Malloch \& Naughton, 2010); the auditors with professional ethics can provide objective opinions (Saputra, 2015); the auditors with professional certificates can provide more reliable information (Cheng et al., 2009). Therefore, it is easy to accept the view that optimizing the structure of employees and cultivating professional audit talents will help to improve audit quality (Earnest, Chamian, \& Saat, 2015). More broadly, the auditor's personal characteristics, such as education, age, specialty, experience and learning ability have a great impact on audit quality ( $\mathrm{Ni}$, Huang, \& Liu, 2019). Then it is easy to understand that the firm's willingness to invest in personnel training and education is very helpful to enhance human capital, which will certainly benefit the quality of audit.

In addition, industry expertise is the basis for accounting firms to provide differentiated services, the higher the level of industry expertise, the more possibility of firms to use professional knowledge and skills to carry out audit work effectively, since expertise can enable auditors to use less effort to better understand the external and internal threats faced by clients (Yen, Lim, Wang, \& Hsu, 2018). Then the earnings management of clients can be timely identified and restrained, and finally audit quality is ensured (Balsam, Krishnan, \& Yang, 2003; Chin \& Chi, 2009; Fleming, Hee, \& N. Romanus, 2014). Ultimately, the industry expertise of the firm is actually the comprehensive embodiment of human expertise accumulated in long terms of learning, training and accumulation. Moreover, in the knowledge age, the rapid technological advances have changed the way of people communication, economic activities operation, and accelerated the processing, updating and transmission of information. It is undeniable that the competition of accounting firms is actually the competition of human capital.

Hence, the current study set forth the following hypothesis for validation:

H1: The firm's human capital has positive relationship with audit quality.

\section{Structural CAPItAl AND AUdit QUality}

Structural capital is one of the two components in Skandia's IC model (Earnest \& Sofian, 2013; Wu Zhanxia, 2011). Afterwards, many scholars follow this view that structural capital (or organizational capital) actually provides the necessary platform for human capital, such as institutional rules, policies, management structure and strategies, which provide an overall and superior environment for human capital to realize value creation by applying knowledge, skills and expertise (Cagáňová et al., 2019). Similar with that, it is suggested that structural capital provides the foundation for the effective integration of human capital and non-human capital in knowledgeable organization (Tang Yan-jun, 2019). After all, the realization of human capital value needs to be combined with other resources to maximize their joint effect. High structural capital enhances the transformation of individuals' value to the overall value of the organization. Furthermore, Bontis et al. have different findings that confirm the impact of structural and relational capital, rather than human capital, on firm performance from the studies on Canada and Malaysia in 1998 and 2000 respectively (Bontis, 1998, 2001).

For accounting firms, the obvious factor in structural capital is the legal form, including limited liability and partnership (Yuan \& Li, 2003). They constitute the main stream organizational forms of service organizations with IC as the main resource. Each form has its own advantages in enhancement of service quality. For example, the partnership form strengthens the mutual supervision among partners and promotes the principle of equal rights and responsibilities (Tang Yan-jun, 2019). The professional independence and cautious attitude of the practitioners are intrinsically motived to perform services, which is what really matters for the maintenance of audit quality (Yuan \& Li, 2003). The limited liability form protects investors' funds, reduces the risk of individual losses and encourage business expansion. Studies show that CPA firms in the form of limited liability are usually large and more capable of providing assured quality audit services (Wong, Firth, \& Lo, 2018). However, in China, the situation of "big but not strong" and "big but not specialized" still remains, since on one hand the talent accumulation and technical advantages based on firm size in China do not reflect sufficiently in audit quality; on the another 
hand the existing large firms in China are mostly formed by merger (Yuan \& Li, 2003), where lack of unified management and the diversity in business bring serious problems in audit quality.

Additionally, the rules of audit pricing of accounting firm must have crucial effect on audit quality, since the audit fees always seem to be a good measure of audit quality (Simunic, 1980). High-quality services are usually associated with high prices (Rahmina \& Agoes, 2014; Suseno, 2013). Typically, the reputable firms charge premium fees to highlight the quality of their services. Besides the reputation effect, the pricing of service is generally based on workload that originating from clients. Ye et al. (2018) imply a direct positive relationship between audit pricing and audit workload and enrich the relationship between audit fees and business complexity by considering the effect of information transparency (Ye, Gao, \& Zheng, 2018). However, there are still some other viewpoints, which show that the high charge may imply economic dependence on clients (Tepalagul \& Lin, 2015; Tobi, Osasrere, \& Emmanuel, 2016), that poses a threat to the audit independence, then eroding the audit quality. More broadly, it is easily understood that fee competition is an effective mechanism to improve audit quality (Asthana, Khurana, \& Raman, 2019), especially in China with less concentrated audit market. Anyhow, audit pricing rule as a concrete structural capital, is very worthy to be studied on the relationship with audit quality.

Hence, the study put forward the following hypothesis for verification:

H2: The firm's structural capital has positive relationship with audit quality.

\section{Relational Capital and Audit Quality}

Market is to provide a multi-party platform, where any organization expected to achieve value creation is bound to be inseparable from the relationship network. The relational capital of an organization is the relationships with customers, suppliers and authorities to achieve organizational goals (Roos, Pike, \& Fernstrom, 2007; Tayles, Pike, \& Sofian, 2007). The stronger the relational capital, the higher the liquidity of information and resources. Scholars defend this view and generally suggest that relational capital is an intangible asset that enhances an organization or individual to acquire resources in the relation network and promotes cooperation between each other and then value creation of the whole society is achieved (Lin, 2001; Portes, 1998). The relational capital also can be seen the continuation of structural capital and provides an important condition for human capital to play its role (Hui \& Chen, 2019).

Relational capital refers to the sum of the key external relationships of the organization, and for accounting firms, it mainly considers the characteristics of the relationship with clients. It is easily to know that long-term cooperation will be good for both sides in understanding and communication, and time is a necessary factor for auditors to gain sufficient client-specific knowledge (Stanley \& DeZoort, 2007). That is audit tenure, which may have a positive effect on audit quality (Rahmina \& Agoes, 2014; Stanley \& DeZoort, 2007). After all, the restricted term of auditor isn't helpful for the collection of experience and the improvement of professional capacity of auditors (Ghosh \& Moon, 2005) and will bring about extra expenses for changing auditors.

However, the trend of audit quality decline is also seen to be hidden in the longer auditor-client relationship. The consequences of some investigations propose that a long auditor-client connection significantly improves the probability of the auditor to issue an unqualified opinion and then audit quality decreases (Vanstraelen, 2000). Therefore, it is not surprising that a series of regulatory policies represented by Sarbanes-Oxley Act 2002 (SOX) were published to require mandatory rotation of main auditors or partners, establish a freezing period for the former auditor to avoid taking up jobs in the clients and prohibit auditors from providing non-audit services (Salawu, 2017; Tepalagul \& Lin, 2015). Similarly, China has also issued the 5-year audit rotation requirements for accounting firms to address the potential erosion of audit independence. It is validated that the audit rotation has significant positive impact on the audit quality, especially for the central state-owned enterprises which take a large part of capital market in China (Wang \& Zhu, 2018). At present, the audit rotation system has become an 
international practice, and the mandatory rotation of auditors has a certain positive impact on the quality of audit.

Hence, the study proposes hypothesis as follows:

H3: The firm's relational capital has positive relationship with audit quality.

\section{SPIRITUAl CAPITAL AND AUdit QUALITY}

As for auditing, it is not the whole thing that requires auditors to detect misstatements with necessary professional competence; more importantly, auditors are also expected to report the misstatements to the public with integrity, honesty, impartiality and objectivity. Both of the two requirements constitute the brief interpretation of audit quality. Moreover, the latter requirement is often the cause of impaired audit quality, that is audit independence (Salawu, 2017; Tepalagul \& Lin, 2015). This is because, in addition to technical ability, the humans' spiritual pursuit, personality, commitment, self-esteem, values and so on are often the internal power to drive their behaviors (Mappanyuki, 2016). It is consistent with the research of Ismail (2005), spiritual capital acts as the core value in IC and mutually impacts with the other three components (Abdullah, 2014; Naslmosavi \& Jahanzeb, 2017).

Audit independence is ever defined as " the auditor's ability to maintain an objective and impartial mental attitude throughout the audit" (Saputra, 2015). So, if auditors cannot remain independent, even if they have the competence to examine misstatements, they may not report the truth (Tepalagul \& Lin, 2015). However, this kind of circumstance where the independence is violated often comes from the client manager power in ethical dilemma situations (Naslmosavi \& Jahanzeb, 2017). It is in this context that the spiritual capital such as personal value, morality, faith and cultural background etc. will have a key impact on maintaining independence in audit behaviors. Independence means an auditor comes to a conclusion only on the basis of professional judgment, and is not affected by external factors, such as interests, familiarities, or other pressure, which may affect the honesty, reality, and uncertainty (Naslmosavi \& Jahanzeb, 2017).

It is suggested that the moral sense is inner self-discipline and motivation to customize rules of individuals, who wrestle with morality to grapple with features of good and evil (Mappanyuki, 2016). Although the moral intensity factor varies with the specific issues in the area of audit, it is based on the opinion that the reduced audit quality may result from ethical judgment (Coram, Glavovic, Ng, \& Woodliff, 2008). The related research holds that the auditor's moral reasoning and the punishment of misreporting are positively related to the auditor's independence, and meanwhile the auditor's independence will affect the firm's investment in audit effort, which consequently will affect the quality of audit work (Yu, 2011).

Moreover, scholars argue that the individuals' behavior is greatly influenced by the situation of morality and values, and they are the main internal motive forces of behavior (Craft, 2013). From these studies, it can be seen how important the morality and values are for decision-making, especially in the audit domain, the ethical decision often determines the service quality. Hence, it is confirmed that morality and ethics are very important aspects to enhance audit quality. What's more, even under the same code of conduct and ethics, human behavior is influenced by different cultural backgrounds. Human beings have their own cultural literacy, which developed from different regions, living experience and education environments (Kleinman \& Lin, 2017). Generally, culture determines the tone, and its influence on behavior is subtle but critical.

Based on the above analysis, the hypothesis is proposed as follows:

H4: The firm's spiritual capital has positive relationship with audit quality. 


\section{METHODOLOGY}

The study carries extensive literature review, and systematically combs the relationship between lincluding its constituent components and the audit quality. A theoretical research framework has been proposed in the next section (Figure 1).

This study plans to collect primary data through questionnaire survey for quantitative analysis So how to determine the target respondents is an important topic. The study will use a non-probability sampling technique based on researcher's judgment to determine the respondents (Hair Jr, Page, \& Brunsveld, 2019; Sekaran \& Bougie, 2016). The quantitative method aims to see the relationship between variables through statistical analysis. The use of research methods is intended to help researchers to assess the extent to which data generated through certain methods objectively reflect reality (Bell, Bryman, \& Harley, 2018).

This study will be conducted for a total of 40 accounting firms approved in 2018 with securitiesqualifications in China. Survey subjects need to be managers and above, since they were considered to have certain insights on organizational IC. Descriptive test, correlation analysis and regression analysis will be performed by use of SPSS software in future study.

\section{RESULTS AND FINDINGS}

As for the auditing area, there is a generally accepted concept about audit quality (DeAngelo, 1981), that is simply refined as a joint probability of the misstatement is detected and reported (Menezes Montenegro \& Brás, 2018). Simply, that is the competence and independence of employees to detect and report the misstatements. Stemming from this interpretation, it leads to reasonable inferences that human capital such as knowledge, skills, expertise and objectivity, plays the leading role in ensuring audit quality. As a result, accounting firms have a broader understanding of human capital and give greater attention to enhancing human capital through education and training.

Structural capital often refers to the rules and systems that regulate internal processes and audit procedures (F. Nancy, 2020), as well as the organizational structure which deeply influences the decisionmaking, risk management and benefit distribution etc. (Tang Yan-jun, 2019). Among them, the firm size is usually a specific reflection of the organization structure, while smaller firms tend to prefer partnerships, and larger ones tend to favor limited liability form (Wong et al., 2018). Besides, the legal organization form is undoubtedly the core element of structural capital, which is the reflection of capital investment structure, and provides the basis for decision-making rights and organizational liability (Tang Yan-jun, 2019). Since both of limited liability and partnership have their own benefits and drawbacks, a special general partnership has been proposed and becomes popular in the world, that is limited liability partnership (LLP), which combines both of the advantages of the two individual form. At the end of 2013, the major accounting firms including the securities-qualified firms have completed their business registration with the strong push of the government and China Institute of Certified Accountants.

Generally, the audit is not a standardized production, and its heterogeneity needs the cooperation between service providers and clients, which will be beneficial to the improvement of audit quality (Knechel, Thomas, \& Driskill, 2019). In the relational capital, the firm's brand image is a concentrated embodiment of degree of its relationship with the outside. As mentioned above, accounting firms with good reputation are expected to provide high-quality services, then it is common to discuss reputation when considering audit quality (Krishnamurthy, Zhou, \& Zhou, 2006) and even sometimes reputation is considered to be synonymous with quality (Francis et al., 2013). What's more, reputation is an intangible asset which means the image and position of an accounting firm evaluated by the external parties in the relationship network, then it is a good reflection of relational capital.

Generally, the importance of spiritual capital is mainly reflected in the dilemma of facing temptation or pressure from clients, where accounting firms pursue interests from clients, however simultaneously they need to be objective and independent due to the professional code of ethics and public expectation. 
Among the concerns about spiritual capital, a number of factors, such as ethics, morality, values and culture, have been mentioned in some studies (Ashkanasy, Windsor, \& Treviño, 2006; Dewing \& Russell, 2004). According to the specific feature of accounting firms, this study will agree with the viewpoint that the audit quality is not only reflected in the final conclusion, but also embodies with every stage in the process, such as the efficiency, quality, timeliness of collecting evidence, professional judgment on information provided, etc. In the process of auditing, the practical behavior of individuals will be influenced by morality, ethics, values and culture, which are the main factors applied as content of spiritual capital (Naslmosavi \& Jahanzeb, 2017).

Therefore, it can be concluded the guaranteed audit quality requires not only the competent employees, efficient and good relations, appropriate structures and rules, but also the strong support of spirituality. Then, referring to the existing literatures on the relationship between the four components of IC and the analysis of specific factors of the accounting firms in this study, the proposed research framework is shown in Figure 1.

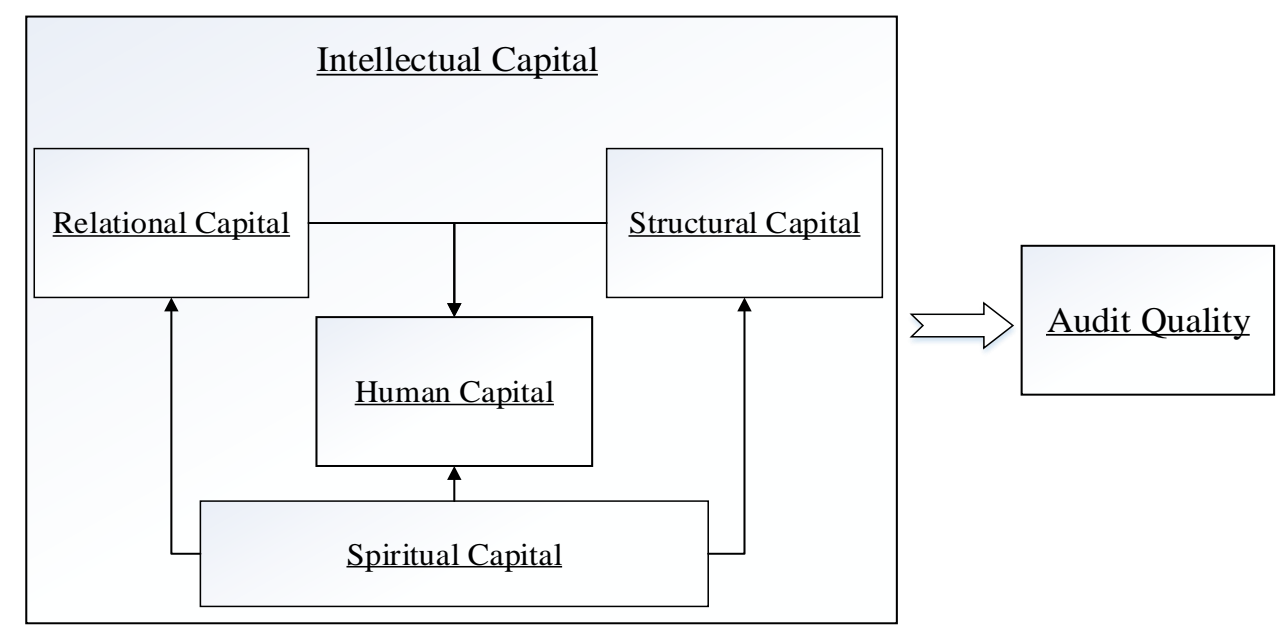

Figure 1. The proposed research framework

The proposed framework further clarifies the crucial role of spiritual capital in IC model for accounting firms and also highlights the key roles of structural and relational capital. Additionally, the human capital undeniably bears the core responsibility in IC model and plays a central leading role. With the joint actions of the four components, the positive relationship between IC and audit quality is clearly displayed. In addition, the hypothesis proposed in this paper will be tested in future empirical research.

\section{CONCLUSION}

This study proposes on integrative research model of intellectual capital (IC) and audit quality for accounting firms, with the opinion that all of the four components including human capital, structural capital, relational capital and spiritual capital, will have critical impact on audit quality. It suggests that in addition to the character of human beings, such as knowledge, expertise, moral, culture and values etc., the rules, structures, norms within the firm and the relationship characteristics of the firm with clients are all closely related to audit quality, which meanwhile enriches the connotation of IC.

Additionally, with the basic framework of IC model, this study explores the specific factors with in the accounting firm industry, which is different from enterprise-based research. That is helpful for accounting firms to accurately identify their IC and its key influencing factors, so as to adjust management strategy reasonably and allocate resources effectively to achieve the overall value maximization. The detailed combing of the firm's key resources will also help to deepen the theoretical understanding of the mechanism of improving audit quality. 
Finally, as important participants in the capital market, accounting firms should be well regulated for healthy development, since its service will ultimately contribute to the efficiency and effectiveness of the market. China's audit market is low concentrated, and characterized with fierce competition and strict control, but the punishment of irregularities is inadequate. In this context, the study of the relationship between audit quality of accounting firms and their core influencing resources will help the market to effectively supervise the industry and promote the healthy development of the market.

\section{Reference:}

Abdullah, D. F. (2014). The Moderated Mediation Effect of the Internal Audit Function and Corporate Governance on Intellectual Capital and Corporate Performance. Universiti Teknologi Malaysia, Adjibolosoo, S. (2004). RESPONDING TO A PLETHORA OF VIEWS REGARDING THE HUMAN FACTOR THEORY: A FRIENDLY DIALOGUE WITH COLLEAGUES. Review of Human Factor Studies, 10(1).

Arens, A. A., Best, P., Shailer, G., \& Fiedler, B. (2013). Auditing, Assurance Services and Ethics in Australia: Pearson Higher Education AU.

Ashkanasy, N. M., Windsor, C. A., \& Treviño, L. K. (2006). Bad apples in bad barrels revisited: Cognitive moral development, just world beliefs, rewards, and ethical decision-making. Business Ethics Quarterly, 16(4), 449-473.

Asthana, S., Khurana, I., \& Raman, K. (2019). Fee competition among Big 4 auditors and audit quality. Review of Quantitative Finance and Accounting, 1-36.

Balsam, S., Krishnan, J., \& Yang, J. S. (2003). Auditor industry specialization and earnings quality. Auditing: A Journal of Practice \& Theory, 22(2), 71-97.

Bell, E., Bryman, A., \& Harley, B. (2018). Business research methods: Oxford university press.

Bontis, N. (1998). Intellectual capital: an exploratory study that develops measures and models. Management Decision.

Bontis, N. (2001). Assessing knowledge assets: a review of the models used to measure intellectual capital. International journal of management reviews, 3(1), 41-60.

Bontis, N., Keow, W. C. C., \& Richardson, S. (2000). Intellectual capital and business performance in Malaysian industries. Journal of intellectual capital.

Cagáňová, D., Hlásniková, P. R., Vraňaková, N., \& Chlpeková, A. (2019). Intellectual Capital as a Key Factor in the Automotive Industry. Mobile Networks and Applications, 24(6), 2024-2031. doi:10.1007/s11036-018-01206-2

Chen, Y.-S., Hsu, J., Huang, M.-T., \& Yang, P.-S. (2013). Quality, size, and performance of audit firms. The International Journal of Business and Finance Research, 7(5), 89-105.

Cheng, Y. S., Liu, Y. P., \& Chien, C. Y. (2009). The association between auditor quality and human capital. Managerial Auditing Journal.

Chin, C. L., \& Chi, H. Y. (2009). Reducing restatements with increased industry expertise. Contemporary Accounting Research, 26(3), 729-765.

Coram, P., Glavovic, A., Ng, J., \& Woodliff, D. R. (2008). The moral intensity of reduced audit quality acts. Auditing: A Journal of Practice \& Theory, 27(1), 127-149.

Cowperthwaite, P. (2010). Culture matters: How our culture affects the audit. Accounting Perspectives, 9(3), 175-215.

Craft, J. L. (2013). A review of the empirical ethical decision-making literature: 2004-2011. Journal of Business Ethics, 117(2), 221-259.

Cziffra, J., Fortin, S., \& Singer, Z. (2019). The Effects of Audit Market Concentration and Auditor Reputation on Audit Quality: Evidence from Government Auditors. Available at SSRN 3202959.

DeAngelo, L. E. (1981). Auditor size and audit quality. Journal of accounting and economics, 3(3), 183199.

Dewing, I. P., \& Russell, P. O. (2004). Accounting, auditing and corporate governance of European listed countries: EU policy developments before and after Enron. JCMS: Journal of Common Market Studies, 42(2), 289-319. 
Earnest, D. F., Chamian, N. F., \& Saat, M. M. (2015). Assesing The Relationship Between Human Capital And Spiritual Capital On Audit Firm's Performance. Jurnal Kemanusiaan, 13(2).

Earnest, D. F., \& Sofian, S. (2013). The mediating role of corporate governance on intellectual capital and corporate performance. Journal of Economics, Business and Management, 1(4), 339-342.

EI-Bannany, M. (2008). A study of determinants of intellectual capital performance in banks: the UK case. Journal of intellectual capital.

F. Nancy, D. S. F. A. R. (2020). Revisiting the Role of Intellectual Capital on Firms' Performance_ Indonesian Evidence.pdf. Advances in Economics, Business and Management Research, 115, 6.

Fleming, D., Hee, K., \& N. Romanus, R. (2014). Auditor industry specialization and audit fees surrounding Section 404 implementation. Review of Accounting and Finance, 13(4), 353-370.

Francis, J. R., Michas, P. N., \& Yu, M. D. (2013). Office size of Big 4 auditors and client restatements. Contemporary Accounting Research, 30(4), 1626-1661.

Ghosh, A., \& Moon, D. (2005). Auditor tenure and perceptions of audit quality. The Accounting Review, $80(2), 585-612$

Hair Jr, J. F., Page, M., \& Brunsveld, N. (2019). Essentials of business research methods: Routledge.

Hui, N., \& Chen, C. (2019). Accounting Firm Industry Expertise, Intellectual Capital and Audit Performance Communication of Finance and Accounting, 23-27. doi:10.16144/j.cnki.issn10028072.2019.03.004

Ismail, M. (2005). The influence of intellectual capital on the performance of Telekom Malaysia. Universiti Teknologi Malaysia,

Kaawaase, T. K., Bananuka, J., Kwizina, T. P., \& Nabaweesi, J. (2019). Intellectual capital and performance of small and medium audit practices. Journal of Accounting in Emerging Economies.

Kleinman, G., \& Lin, B. B. (2017). Audit regulation in an international setting: Testing the impact of religion, culture, market factors, and legal code on national regulatory efforts. International Journal of Disclosure and Governance, 14(1), 62-94.

Knechel, W. R., Thomas, E., \& Driskill, M. (2019). Understanding financial auditing from a service perspective. Accounting, Organizations and Society, 101080.

Krishnamurthy, S., Zhou, J., \& Zhou, N. (2006). Auditor reputation, auditor independence, and the stock - market impact of Andersen's indictment on its client firms. Contemporary Accounting Research, 23(2), 465-490.

Lee, C.-C., \& Lin, C.-K. (2019). The major determinants of influencing the operating performance from the perspective of intellectual capital: Evidence on CPA industry. Asia Pacific Management Review, 24(2), 124-139.

Lin, N. (2001). Building a Network Theory of Social Capital. En Social Capital: Theory and Research, eds. Nan Lin, Karen Cook y Ronald Burt. In: New York, Aldine de Gruyter.

Long, B. S., \& Mills, J. H. (2010). Workplace spirituality, contested meaning, and the culture of organization. Journal of organizational change management.

Mahdi Salehi, A. J. a. Z. N. (2017). The effect of audit fees pressure on audit quality during the sanctions in Iran. International Journal of Law and Management, 66-81.

Malloch, T. R. (2010). Spiritual capital and practical wisdom. The Journal of Management Development, 29(7-8), 755-759.

Mappanyuki, R. (2016). Effects Spiritual Influence Of Auditors, Complexity Task, Ethics Auditor And Auditor Expertise On The Performance Auditor Withaccounting Information Systems With Moderating Variabel (Empirical Study on BPKP Representative Office South Sulawesi). Southeast Asia Journal of Contemporary Business, Economics, and Law, 9(1), 2289-1560.

Marr, B. (2008). Intangible asset measurement, accountants today. Kuala Lumpur, Malaysia.

Marr, B., \& Moustaghfir, K. (2005). Defining intellectual capital: a three - dimensional approach. Management Decision.

Menezes Montenegro, T., \& Brás, F. A. (2018). A review of the concept and measures of audit quality across three decades of research. International Journal of Accounting, Auditing and Performance Evaluation, 14(2-3), 183-253. 
Modarres, A., \& Rafiee, A. (2011). Influencing factors on the ethical decision making of Iranian accountants. Social Responsibility Journal.

Mohamed, D. M., \& Habib, M. H. (2013). Auditor independence, audit quality and the mandatory auditor rotation in Egypt. Education, Business and Society: Contemporary Middle Eastern Issues.

Naslmosavi, S., \& Jahanzeb, A. (2017). The effect of spiritual capital of individuals on independent auditor's opinion: evidences from Iranian auditors. Asian Journal of Business Ethics, 6(2), 131152. doi:10.1007/s13520-016-0069-z

Ni, J., Huang, X., \& Liu, Q. (2019). Research on the influence of auditor's personal characteristics on audit quality. Journal of Jiangxi University of Science and Technology, 5. doi:10.13265/j.cnki.jxlgdxxb.2019.06.024

Portes, A. (1998). Social capital: Its origins and applications in modern sociology. Annual review of sociology, 24(1), 1-24.

Porth, S. J., McCall, J., \& Bausch, T. A. (1999). Spiritual themes of the "learning organization". Journal of organizational change management.

Rahmina, L. Y., \& Agoes, S. (2014). Influence of auditor independence, audit tenure, and audit fee on audit quality of members of capital market accountant forum in Indonesia. Procedia-Social and Behavioral Sciences, 164, 324-331.

Roos, G., Pike, S., \& Fernstrom, L. (2007). Managing intellectual capital in practice: Routledge.

Roosevelt Malloch, T., \& Naughton, M. (2010). Spiritual capital and practical wisdom. Journal of Management Development, 29(7/8), 755-759. doi:10.1108/02621711011059194

Salawu, M. K. (2017). Factors influencing auditor independence among listed companies in Nigeria: Generalized method of moments (GMM) approach. International Journal of Economics and Finance, 9(8), 191.

Saputra, W. (2015). The Impact Of Auditor's Independence On Audit Quality: A Theoretical Approach. International Journal of Scientific \& Technology Research, 4(12), 348-353.

Sekaran, U., \& Bougie, R. (2016). Research methods for business: A skill building approach: John Wiley \& Sons.

Simunic, D. A. (1980). The pricing of audit services: Theory and evidence. Journal of accounting research, 161-190.

Stanley, J. D., \& DeZoort, F. T. (2007). Audit firm tenure and financial restatements: An analysis of industry specialization and fee effects. Journal of Accounting and Public Policy, 26(2), 131-159.

Sundgren, S., \& Svanström, T. (2013). Audit office size, audit quality and audit pricing: evidence from small-and medium-sized enterprises. Accounting and Business Research, 43(1), 31-55.

Suseno, N. S. (2013). An empirical analysis of auditor independence and audit fees on audit quality. International Journal of Management and Business Studies, 3(3), 82-87.

Tang Yan-jun, J. Y.-m. (2019). Organizational Prototype and Audit Quality : the Effect of orgnization structure Conversion of Accounting Firm. 116-120. doi:10. 19641/j. cnki. 42-1290/f. 2019

13. 019

Tayles, M., Pike, R. H., \& Sofian, S. (2007). Intellectual capital, management accounting practices and corporate performance. Accounting, Auditing \& Accountability Journal.

Tepalagul, N., \& Lin, L. (2015). Auditor independence and audit quality: A literature review. Journal of Accounting, Auditing \& Finance, 30(1), 101-121.

Tobi, B. A., Osasrere, A. O., \& Emmanuel, U. (2016). Auditor's independence and audit quality: A study of selected deposit money banks in Nigeria. International Journal of Finance and Accounting, 5(1), 13-21.

Vanstraelen, A. (2000). Impact of renewable long-term audit mandates on audit quality. European Accounting Review, 9(3), 419-442.

Wang, L., \& Zhu, L. (2018). State Ownership, Auditor Rotation and Audit Quality. Paper presented at the 2nd International Conference on Culture, Education and Economic Development of Modern Society (ICCESE 2018). 
Wong, R. M., Firth, M. A., \& Lo, A. W. (2018). The impact of litigation risk on the association between audit quality and auditor size: Evidence from China. Journal of International Financial Management \& Accounting, 29(3), 280-311.

Wu Zhanxia, Z. J., Lin Mengqi. (2011). An Empirical Study of Relationship between the Intellectual Capital and Audit Results. International Conference on Business Computing and Global Informatization, 4.

Ye, Q., Gao, J., \& Zheng, W. (2018). Accounting Standards, Earnings Transparency and Audit Fees: Convergence with IFRS in China. Australian Accounting Review, 28(4), 525-537.

Yen, J.-C., Lim, J.-H., Wang, T., \& Hsu, C. (2018). The impact of audit firms' characteristics on audit fees following information security breaches. Journal of Accounting and Public Policy, 37(6), 489507.

Yu, H.-C. (2011). Legal systems and auditor independence. Review of Accounting Studies, 16(2), 377.

Yuan, H., \& Li, H. (2003). The organizational form and size of accounting firms and audit quality. Audit Research, 32-37.

Zhang, H. (2014). Discussion on China's National Audit Culture. Finance and accounting monthly, 3. doi:10.19641/j.cnki.42-1290/f.2014.08.027 